Article

\title{
New insights into recovery of copper and gold from old flotation tailings from Bor, Serbia
}

\author{
Erdem Özdemir ${ }^{1}$, Aleksandra Lang ${ }^{2}$, Juha Saari ${ }^{3}$ and Jussi Liipo ${ }^{4, *}$ \\ 1 erdem.ozdemir@mogroup.com \\ 2 aleksandra.lang@mogroup.com \\ 3 juha.saari@mogroup.com \\ $4^{*}$ jussi.liipo@mogroup.com \\ *Author to whom correspondence should be addressed \\ Metso Outotec Research Center, Kuparitie 10, FI- 28101, Pori, Finland
}

\begin{abstract}
Mining and processing tailings often contain significant amounts of valuable metals, that can represent valuable sources of secondary raw materials. Especially this is case in early-stage operations, in which the head grades were higher, and the tailings were higher grade. These tailings can also present a substantial risk to the environment. Serbia has copper deposits which have been exploited since ancient times, and these operations have generated large amounts of mineral processing tailings. The main objective of this study is to show how valuables can be recovered from chemically and mineralogically challenging tailings. After detailed chemical and mineralogical characterization, the laboratory scale flotation tests focused on evaluating the effect of particle size, different types of collectors, $\mathrm{pH}$, and pulp potential. Based on the test work, copper and gold can be recovered effectively into pyrite concentrate.
\end{abstract}

Keywords: copper, gold, mineralogy, tailings, flotation, value recovery, modelling

\section{Introduction}

Efficient processing of tailings, i.e., mine waste, is crucial to eliminate environmental risks often connected with tailings ponds. Tailings also represent a valuable source of secondary raw materials, which has been earlier neglected as an opportunity, but now seen globally .as potentially exploitable and cost saving raw material sources, since they consist of already mined and comminuted minerals [1-5].

The present research is a part of the European Institute of Innovation and Technology (EIT) funded RIS-CuRE project, which aims at zero waste extraction of valuable metals from the old Bor tailings containing copper and gold. Serbia has copper deposits that have been exploited since ancient times, and date back to 4500 B.C. These operations have generated large amounts of mineral processing tailings. The Bor copper mine located in the eastern part of Serbia started exploiting the high grade, 17\% Cu, copper ores in 1903 [6] the open-pit mining started in 1912 and continued until 1986 with decreasing copper grades [7].

During these mining operations, approximately $700 \mathrm{Mt}$ of waste rocks and tailings were disposed In the Bor Valley [8]. The dumped tailings are extremely acid, with $\mathrm{pH}$ values ranging between 2 and 4.25 [9], which is mainly due to the decomposition of abundant pyrite, that has led to acid generation [10-11].

These acid conditions facilitate the mobility and bioavailability of toxic heavy metals. the soil surrounding the old flotation tailings pond is contaminated with metallic elements, with particularly high values obtained for iron, copper, and arsenic concentrations 
[12-13]. Overall, a century of mining has left its mark on the Bor area landscapes being one of the most polluted places in Serbia [7].

In the case of a tailings dam failure there is the potential for a significant portion of the toxic material to run directly to the Borska River and onward to the Danube River, with enormous environmental consequences to the entire region $[9,14]$.

Reprocessing of tailings can enable reduction of the acid generation and following release of metals to waterways and soils by removing pyrite with simultaneous recovery of valuables. Several studies have been conducted at laboratory scale to recover copper and gold from the Bor tailings by acid leaching $[8,15]$, acid leaching followed by flotation of leaching residue [16] leading to copper and sulfur recoveries of $70 \%$ and $77 \%$, correspondingly. Conić et al. [15] concluded, that the most efficient technology for copper recovery from the old flotation tailings of the Bor copper mine was leaching with biogenic lixiviant. Falagán et al. [2] reached copper recoveries of over $90 \%$ by bioleaching.

Markovic et al [9] and Han et al. [17] used flotation to recover valuables from the Bor tailings. Markovic et al [9] achieved flotation recovery of copper over $97 \%$ and pyrite recovery over $87 \%$. Copper and pyrite grades in bulk concentrate were $1.34 \%$ and $42.74 \%$, correspondingly. Recoveries of gold and silver were above $60 \%$.

\section{Materials and Methods}

The old Bor flotation tailings have been disposed in the Bor River valley from 1933 to 1987 into two tailings ponds, that covers an area of approximately $1.6 \mathrm{~km}^{2}$ and consists of 27 million tons of tailings with an average copper and gold contents in the range of 0.2$0.3 \% \mathrm{Cu}$ and 0.3- 0.6ppm Au, correspondingly [18].

About $230 \mathrm{~kg}$ of tailings was sampled from six drill holes and delivered to Metso Outotec Research Center, Pori, Finland for characterization and beneficiation test work. The received sample was homogenized and divided into subsamples. Particle size $\mathrm{d} 80$ and $\mathrm{d}_{50}$ were $132 \mu \mathrm{m}$ and $36 \mu \mathrm{m}$, by sieve analysis, correspondingly.

\subsection{Chemical composition of tailings}

The chemical analysis of metals in solids was conducted using Inductive Coupled Plasma Optical Emission Spectrometry (ICP-OES, Thermo Scientific iCAP 6000) after total dissolution. The total carbon and sulfur concentrations were determined by a combustion method (Eltra CS-2000). The gold content was determined Inductive Coupled Plasma Mass Spectrometry (ICP-MS, Thermo Scientific iCAP Q).

In addition, the copper contents were determined according to the four-stage sequential copper phase assay procedure described by Young [19] and further developed by Metso Outotec. This procedure enables the quantification of different copper sulphates, oxides, secondary copper sulfides, and primary copper sulfides by using the element-tomineral conversion (EMC) method, [20-21], included in the HSC Chemistry® 10 software [22].

\subsection{Mineral composition of tailings}

The main minerals and their modes of occurrence were first studied per size fraction by optical microscopy (Zeiss Axio Imager M2m) and X-ray diffraction (PAnalytical Aeris). Scanning electron microscopy and liberation measurements were performed by using a field emission scanning electron microscope (JEOL JSM 7000F) equipped with an Oxford Instruments energy-dispersive spectrometer (X-Max 80) coupled with AZtec Mineral liberation measurement software.

\subsection{Grinding tests}

Grinding test was performed by using mild steel laboratory ball mill $(215 \mathrm{~mm}$ height x $205 \mathrm{~mm}$ diameter) using $27 \mathrm{~mm}(3.3 \mathrm{~kg})$ and $19 \mathrm{~mm}(8.7 \mathrm{~kg})$ balls with $65 \%$ solid density with the grinding times of 5, 10, 20,40, 80, and 105 minutes. 


\subsection{Flotation test work}

Bor flotation test work was carried out by using a laboratory type Outotec GTK Lab Cell flotation machine. GTK flotation lab cell is equipped with adjustable external water feed pump for adjusting constant pulp level. Froth is recovered by automatic froth scraper system. The flotation and grindability test work were carried out with Pori tap water. The $\mathrm{pH}$ of the slurry was measured as 3.5 .

Makeup water was added during the flotation tests to obtain constant pulp level in the flotation cell. Bor rougher flotation tests were carried out by $35 \%$ solid ratio using $1 \mathrm{~kg}$ and $2 \mathrm{~kg}$ feeds in 2- and 4-liters flotation cell, respectively. The air flow was set to $31 / \mathrm{min}$ throughout the flotation test. Moreover, air was fed in 15-20 seconds delayed for the purpose of building froth. Once the froth reaches the discharge lip, the flotation time and froth scraper were started. An impeller rotational speed was selected to achieve a suitable pulp suspension in the flotation cell. Impeller rotational speed of $1300 \mathrm{rpm}$ and $1500 \mathrm{rpm}$ were used in $2 \mathrm{~L}$ and $4 \mathrm{~L}$ respectively. Rougher flotation concentrates were collected at 2, 6, 14, 22, and 30 minutes, to determine the flotation kinetics (Figure 1).

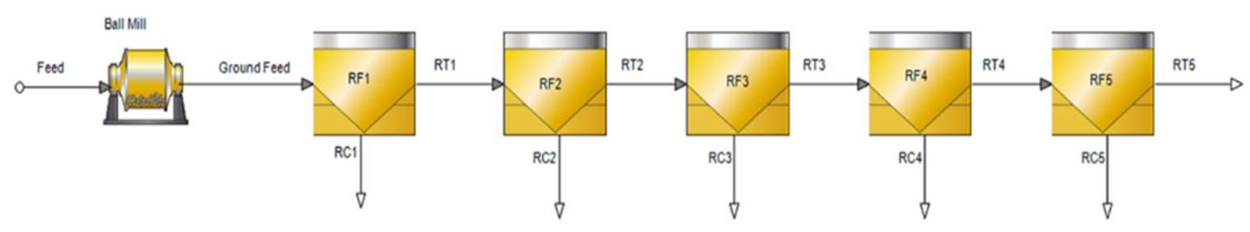

Figure 1. Flow sheet for kinetic rougher flotation test, RC1-6 refers to rougher concentrates 1 to 6 .

\section{Results}

\subsection{Chemical and mineral composition}

Based on the assays, the received old Bor tailings sample contains $0.24 \%$ copper, $7.7 \%$ iron, $7 \%$ sulfur and $0.41 \mathrm{ppm}$ gold and $2.2 \mathrm{ppm}$ silver. Almost $60 \%$ of the samples total copper is carried by water and acid soluble copper minerals.

The mineralogy of the old Bor tailings is complex due to the subsequent alteration of main primary sulfides and occurrence of subsequent water and acid soluble copper minerals. Copper in the old Bor tailings is carried mainly by secondary water and acid soluble, chalcanthite -type minerals $(57.5 \%)$ and by relicts of primary chalcopyrite $(16.6 \%)$, enargite (16.3\%) and covellite (9.6\%).

\subsection{Flotation test work}

To recover both copper minerals and pyrite into concentrate, 24 flotation tests with Bor tailings were carried out at low $\mathrm{pH}$ of 9.75- 9.85. In the base case, sodium iso-butyl xanthate $(\mathrm{SiBX}$ ) was the main collector and polypropylene glycol methyl ether (Dow froth 250) was the main frother. Moreover, the dissolved copper can be precipitated by adjusting $\mathrm{pH}$ and Eh and floated into concentrate in presence of SiBX collector. The reagent dosage were $140 \mathrm{~g} / \mathrm{t}$ and $80 \mathrm{~g} / \mathrm{t}$, correspondingly and particle size distribution ( $\mathrm{P}_{80}$ ) was $26 \mu \mathrm{m}$.

\subsubsection{Effect of particle size on bulk flotation}

The purpose was to determinate the optimum particle size distribution for bulk flotation stage. Different grinding times were applied to produce particle size distribution (P8) from $50 \mu \mathrm{m}$ down to $13.4 \mu \mathrm{m}$, were applied in presence of SIBX and Dow froth 250. The highest copper grade, $0.49 \% \mathrm{Cu}$, was achieved when $\mathrm{P}_{80}$ was $50 \mu \mathrm{m}$. Although with finer $P_{80}$ of particle size was $26 \mu \mathrm{m}$, highest copper recovery of $93 \%$ was obtained, but the concentrate grade, $0.46 \% \mathrm{Cu}$, remained slightly lower. The lowest copper recovery $(78 \%)$ 
and grade $(0.25 \% \mathrm{Cu})$ to bulk concentrate was obtained without grinding at $132 \mu \mathrm{m}\left(\mathrm{P}_{80}\right)$. Decreasing the particle size of the feed improved both recovery and grade as the degree of liberation of sulfides increased (Figure 2).
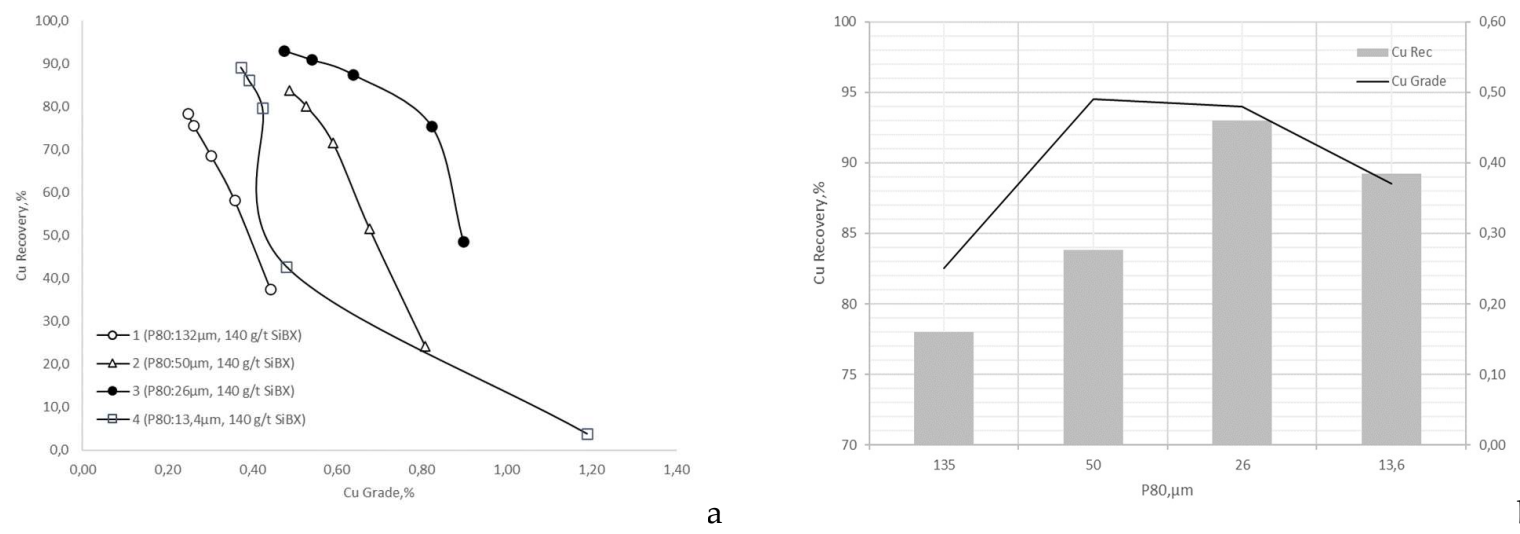

Figure 2. Effect on particle size distribution to flotation performance a) copper grade versus copper recovery and b) bulk copper recovery and grade by $\mathrm{P}_{80}$.

\subsubsection{Effect of different promoters on bulk flotation}

Thiocarbamate and dithiophosphates are one of the most important collectors enabling robust flotation performance especially for oxidized copper minerals like Bor tailings. Therefore, Solvay's 3418A (Sodium di-isobutyl-dithiophosphinate) and XD 5002 (alkyl thiocarbamate) were tested to reach better flotation performance.

According to the copper recoveries and grades, overall flotation kinetics are almost identical for both collectors. The usage of different types of collectors didn't improve the flotation performance as well as selectivity (Figure 3).
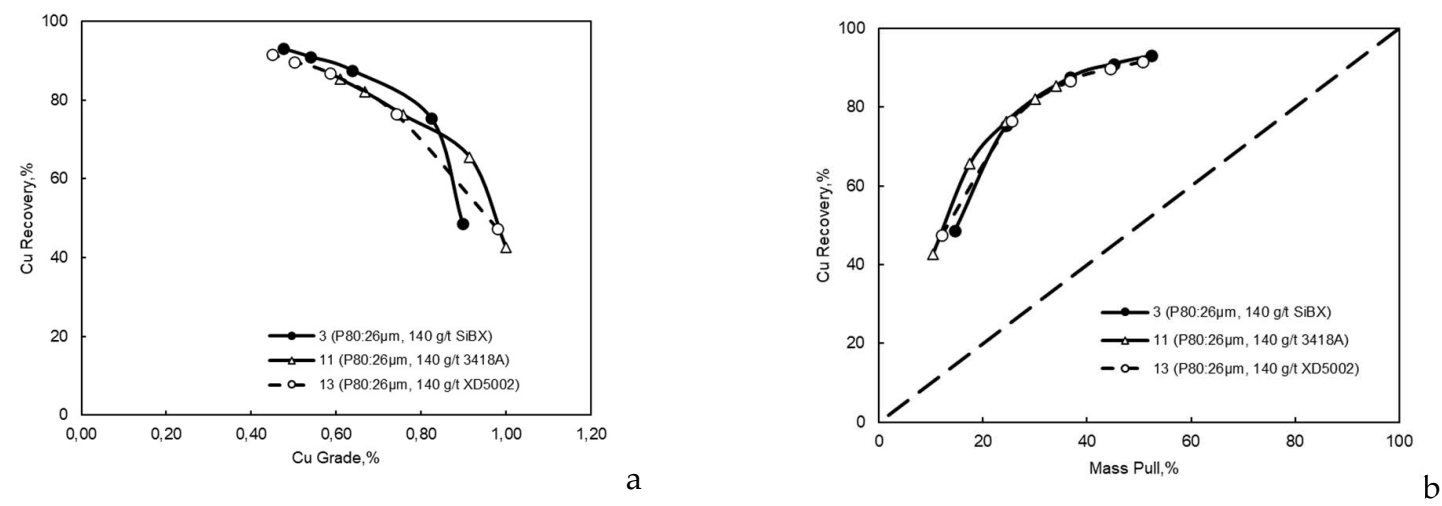

Figure 3. Effect of different promoters on bulk flotation performance a) copper grade versus copper recovery and b) copper recovery against mass pull

\subsubsection{Effect of pulp potential}

In the presence of oxidized minerals, sulfurizing agents such as sodium sulfide $(\mathrm{Na} 2 \mathrm{~S})$ and sodium hydrosulfide $(\mathrm{NaSH})$ are one of the best effective way to increase recovery of oxidized minerals. Heavily oxidized sulfide minerals mineral surface can be transformed to the hydrophobic surface by flotation modifiers such as $\mathrm{NaSH}$. Therefore, $\mathrm{NaSH}$ make such oxidized minerals more floatable in presence of xanthate or thiol collectors [23]. 
Copper phase of Bor tailings mostly consist of oxide type minerals. In case of sulfurizing method, pulp potential need to be adjusted precisely to avoid excessive dosages. Therefore, different pulp potentials were adjusted using by $\mathrm{NaSH}$.

By reducing the pulp potential using by $\mathrm{NaSH}$, flotation rate increased, but it also effected to copper grade and recovery negatively. Also, decreasing the pulp potential below $-150 \mathrm{mV}(\mathrm{Pt}-\mathrm{Ag} / \mathrm{AgCl})$ by $\mathrm{NaSH}$, the selectivity of flotation against gangue minerals decreased (Figure 4).
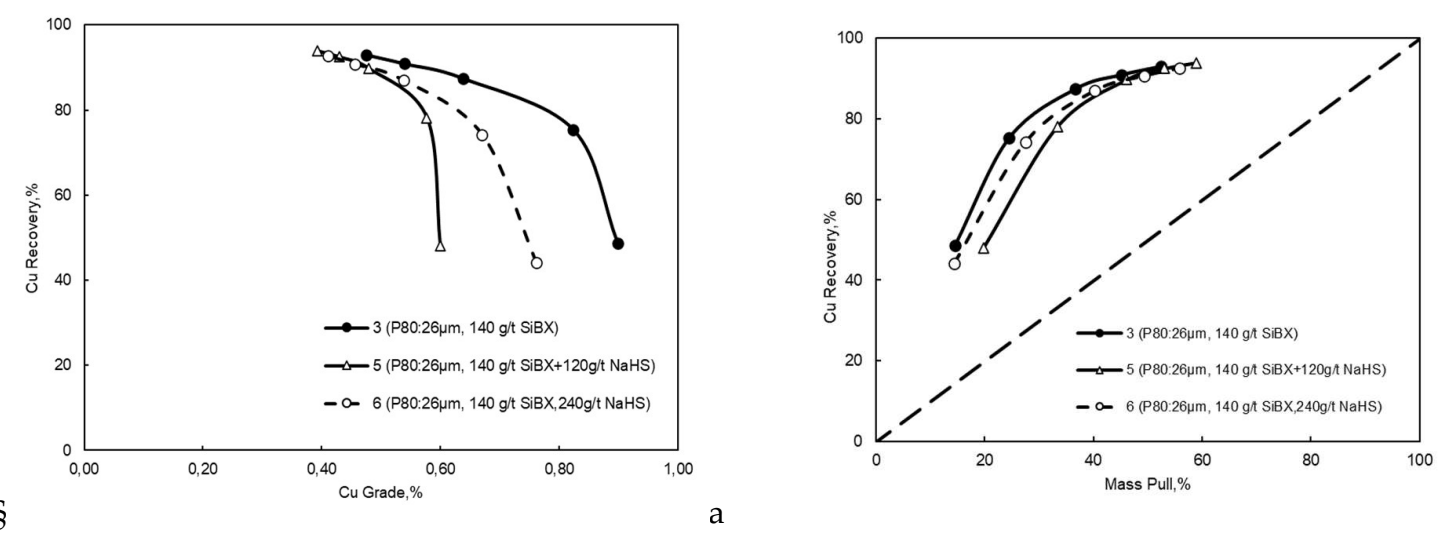

a

Figure 4. Effect of pulp potential on bulk flotation performance a) copper grade versus copper recovery and b) copper recovery against mass pull

\subsubsection{Effect of $\mathrm{Na}_{2} \mathrm{SiO}_{3}$ on cleaner stages}

The best bulk flotation test conditions were used to produce material for cleaner kinetic tests (Figure 5). In the cleaner tests, all reagents were added as stage wise to avoid excessive dosages and obtain proper kinetic trends. According to the results, addition of $250 \mathrm{~g} / \mathrm{t} \mathrm{Na} \mathrm{SiO}_{3}$ (Zeopol 30) didn't improve the copper grades in first cleaner concentrate. Based on the results, there is no dramatic effect of $\mathrm{Na}_{2} \mathrm{SiO}_{3}$ in first cleaner stage. Moreover, sulfidation also decreased the selectivity of flotation process (Figure 6).

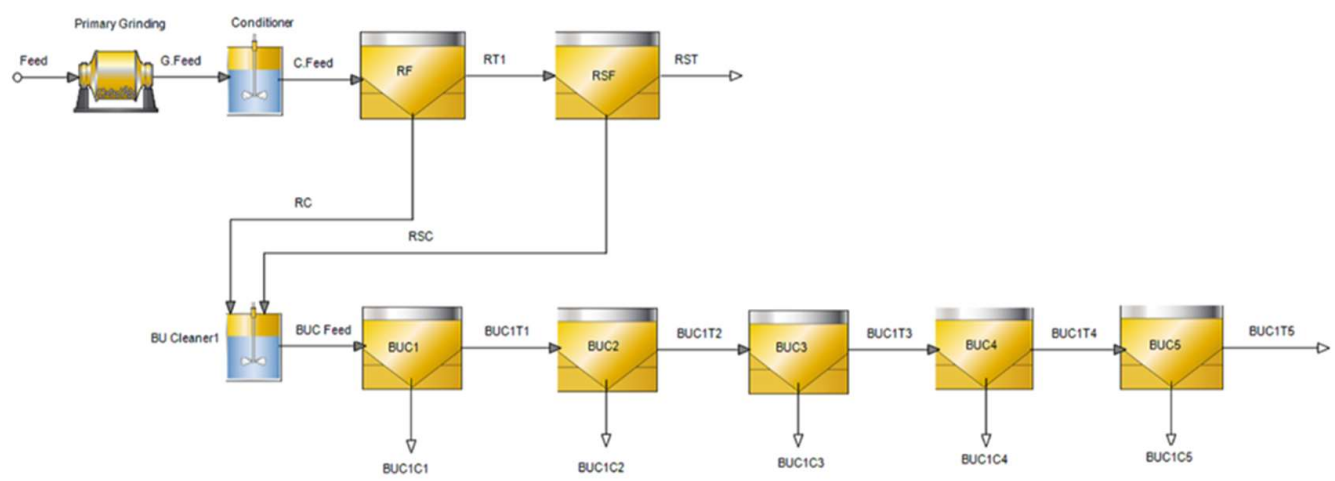

Figure 5. Flow sheet for kinetic cleaner flotation tests. 

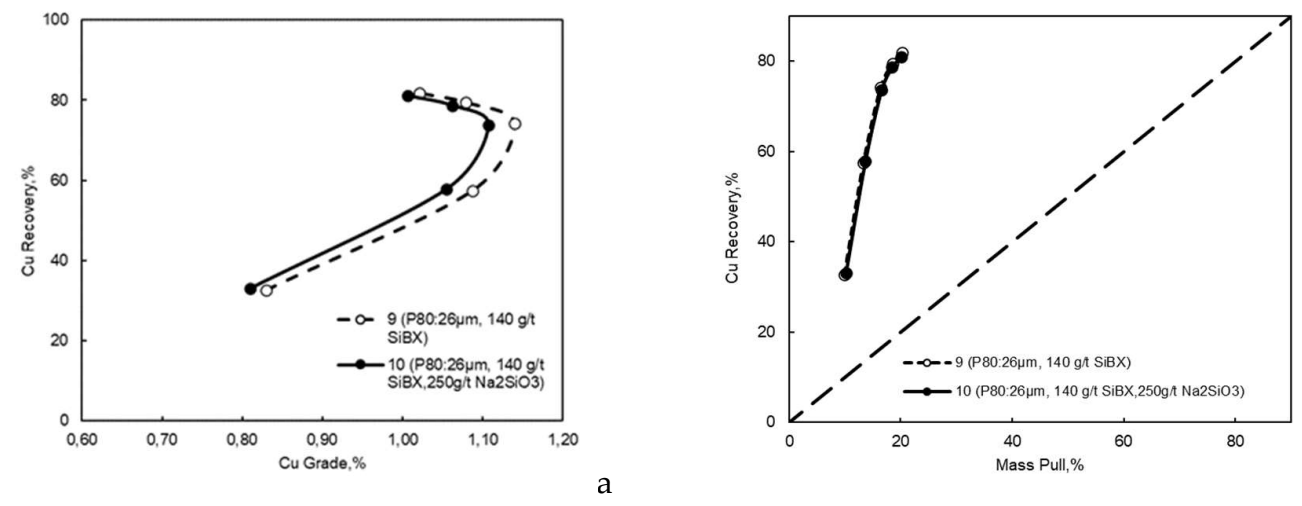

a

b

Figure 6. Effect of $\mathrm{Na}_{2} \mathrm{SiO}_{3}$ on cleaner flotation performance a) copper recovery versus copper grade and b) copper recovery against mass pull

\subsubsection{Flowsheet simulation}

Simulation was carried out on developed preliminary flowsheet including rougher, scavenger, and two bulk cleaner stages by HSC Chemistry ® 10 software [22] to determine final copper and pyrite recovery in continuous process.

Mass balances were calculated including grades and recoveries for each mineral in each stream. HSC Sim Model fit ${ }^{\circledR}$-tool [22] was used for mass balance, middle stream calculation and Klimpel flotation model for batch flotation to calculate kinetic parameters such as maximum recovery $\left(R_{\max }\right)$ and flotation rate constant $\left(\mathrm{k}_{\max }\right)$. The Klimpel model (Equation 1), $R_{\max }$ showing the highest possible recovery for each mineral and the $\mathrm{k}$ of rectangular distribution showing how fast each mineral is floated.

$$
R=R_{\max }\left\{1-\frac{1}{k t}\left[1-e^{-k t}\right]\right\}
$$

where, $\mathrm{t}$ is the cumulative residence time and $\mathrm{R}_{\max } \leq 1$.

HSC model fit draws kinetic curves for each mineral and define values for $\mathrm{k}_{\max }$ and $R_{\max }$. These values were then used for flotation modelling. A 100 tph plant capacity was selected and carried out continuous simulation using by $R_{\max }$ and kinf constants with rectangular distribution method.

According the simulation results, $50,7 \% \mathrm{~S}$ pyrite (sulfur) concentrate can be produced at $85 \%$ recovery. Additionally, the pyrite concentrate contains $1.65 \% \mathrm{Cu}$ and $9 \mathrm{ppm} \mathrm{Au}$ with the recovery of $48 \%$ and $80 \%$, respectively (Figure 7 ). 


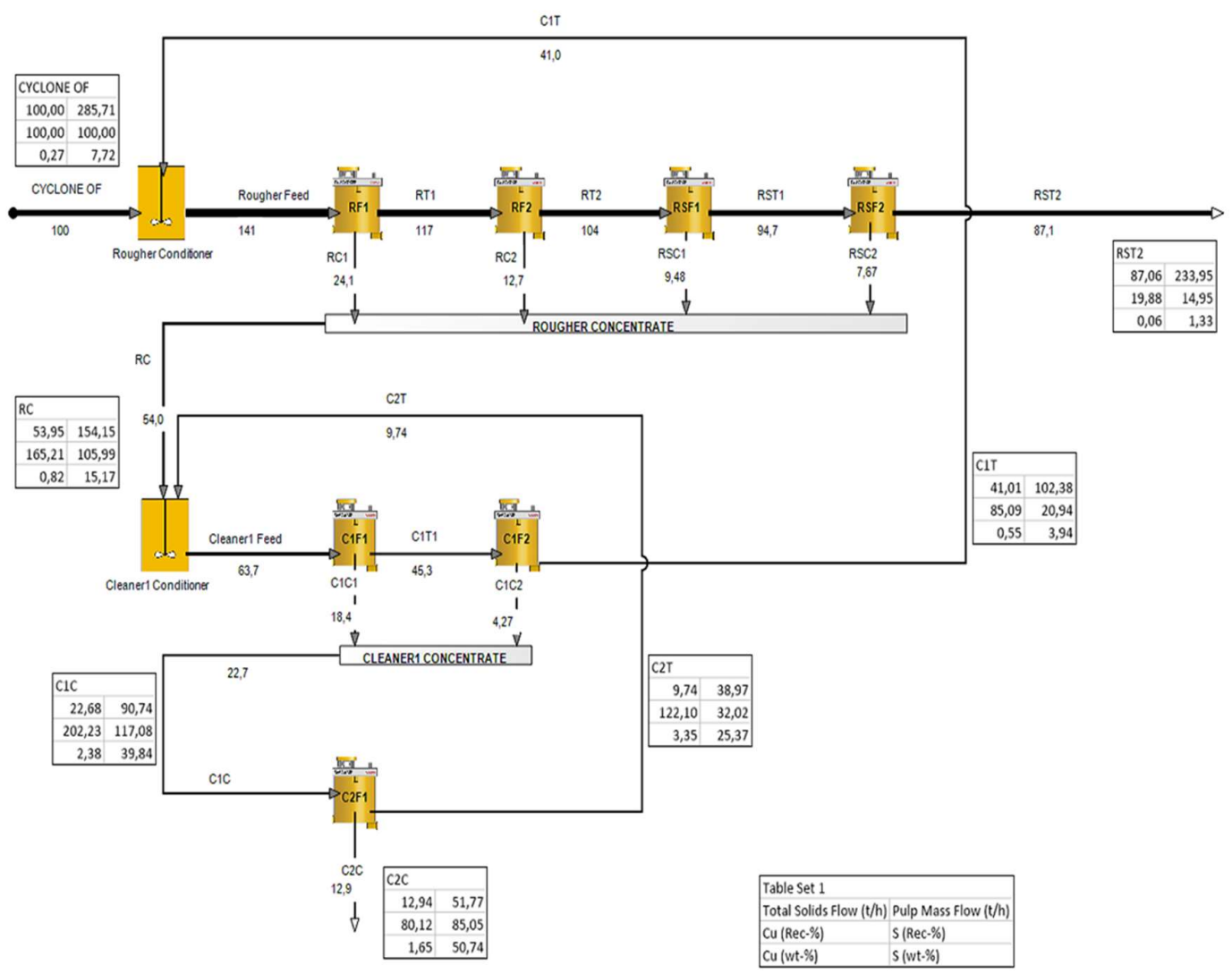

Figure 7. Simulated flowsheet with copper and sulfur grades and recoveries

\section{Discussion and conclusions}

The main objective of the test work carried out by Metso Outotec was to show how valuables can be recovered from chemically and mineralogically challenging tailings. The Bor tailings contain $0.24 \%$ copper, $0.41 \mathrm{ppm}$ gold and $2.2 \mathrm{ppm}$ silver. Based on detailed chemical and mineralogical characterization, the main sulfide in the tailings is pyrite with accessory chalcopyrite, enargite, covellite and chalcanthite. Half of the total copper content is water and acid soluble.

In the laboratory scale flotation tests, the focus is on evaluating the effect of particle size, different types of collectors, $\mathrm{pH}$, and pulp potential on achieved grades and recoveries. The dissolution of copper can be prevented by adjusting $\mathrm{pH}$ and Eh.

Based on the test work conducted, both copper and gold can be recovered effectively into pyrite concentrate. Finally, $85 \%$ of sulfur and $80 \%$ of copper were recovered in into concentrate. The recoveries for gold and silver were $49 \%$ and $84 \%$, correspondingly. The final concentrate contained $50.7 \%$ sulfur, $1.65 \%$ copper and 9 ppm gold.

Reprocessing of old mine tailings can be both economic and environmentally friendly solution by recovering a substantial amount of copper, gold, and sulfur into concentrate, that can be utilized in smelting as a source of energy or fed to sulfuric acid plants, and at the same time reducing the environmental impact caused by acid mine drainage. 
Author Contributions: Conceptualization, J.L., A.L. and E.Ö.; methodology, E.Ö and A.L.; resources, J.S.; writing-original draft preparation, J.L.; writing-review and editing, E.Ö, A.L, and J.S.; supervision, J.S.; All authors have read and agreed to the published version of the manuscript

Funding: This research has received funding from the European Institute of Innovation and Technology (EIT). This body of the European Union receives support from the European Union's Horizon 2020 research and innovation program.

Acknowledgments: The laboratory technicians at Metso Outotec Research Center are appreciated for their skillful assistance in experimental and analytical work.

Conflicts of Interest: The authors declare no conflict of interest. 


\section{References}

1. Lutandula, M.S.; Maloba, B. Recovery of cobalt and copper through reprocessing of tailings from flotation of oxidised ores, Journal of Environmental Chemical Engineering 2013, 1 1085-1090

2. Falagán, C.; Grail, B.M.; Johnson, D.B.; New approaches for extracting and recovering metals from mine tailings. Minerals Engineering, 2017, 106, pp.71-78.

3. Babel, B.; Penz, M.; Schach, S.; Boehme, S.; Rudolph, M.; Reprocessing of a Southern Chilean Zn Tailing by Flotation-A Case Study, Minerals, 2018, 8, 295.

4. Drobe, M.; Haubrich, F.; Gajardo, M.; Marbler, H. Processing Tests, Adjusted Cost Models and the Economies of Reprocessing Copper Mine Tailings in Chile. Metals, 2021, 11(1), p.103.

5. Shengo, L.M. Potentially Exploitable Reprocessing Routes for Recovering Copper and Cobalt Retained in Flotation Tailings. Journal of Sustainable Metallurgy, 2021, 7(1), pp.60-77.

6. EJATLAS; Environmental Justice Atlas: Over a century of pollution from the Bor mines, Serbia. Available online ULR https://ejatlas.org/conflict/over-a-century-of-the-pollution-from-the-bor-mines-serbia (accessed on November $4^{\text {th }}$, 2021)

7. Urošević, S.; Vuković, M.; Pejčić, B. Štrbac, N. Mining- metallurgical sources of pollution in Eastern Serbia and environmental consciousness, Revista Internacional de Contaminación Ambiental, 2018, vol. 34, no. 1, pp. 103-115.

8. Antonijević, M.M.; Dimitrijević, M.D.; Stevanović, Z.O.; Serbula, S.M. Bogdanovic, G.D. Investigation of the possibility of copper recovery from the flotation tailings by acid leaching. Journal of hazardous materials, 2008, 158(1), pp.23-34.

9. Markovic, Z.; Vusovic, N.; Milanovic, D. Old copper flotation tailings waste processing, Proceedings of XXV International Mineral Processing Congress (IMPC). Brisbane, QLD, Australia. 6- 10 September 2010, 2010, 3825- 2829

10. Jambor, J.L.; Chapter 3, Mineralogy of sulfide-rich tailings and their oxidation products. In Short course handbook on environmental geochemistry of sulfide mine-wastes. 1994, Mineralogical Association of Canada, Nepean.

11. Đorđievski, S.; Ishiyama, D.; Ogawa, Y.; Stevanović, Z. Mobility and natural attenuation of metals and arsenic in acidic waters of the drainage system of Timok River from Bor copper mines (Serbia) to Danube River. Environmental Science and Pollution Research, 2018, 25(25), pp.25005-25019.

12. Antonijević, M.M.; Dimitrijević, M.D.; Milić, S.M.; Nujkić, M.M. Metal concentrations in the soils and native plants surrounding the old flotation tailings pond of the Copper Mining and Smelting Complex Bor (Serbia). Journal of environmental monitoring, 2012, 14(3), pp.866-877.

13. Filimon, M.N.; Caraba, I.V.; Popescu, R.; Dumitrescu, G.; Verdes, D.; Petculescu Ciochina, L.; Sinitean, A. Potential Ecological and Human Health Risks of Heavy Metals in Soils in Selected Copper Mining Areas-A Case Study: The Bor Area. International Journal of Environmental Research and Public Health, 2021, 18(4), p.1516.

14. Stanković, V.; Milošević, V.; Milićević, D.; Gorgievski, M.; Bogdanović, G. Reprocessing of the old flotation tailings deposited on the RTB Bor tailings pond-a case study. Chemical Industry and Chemical Engineering Quarterly, 2018, 24(4), pp.333-344.

15. Conić, V.; Stanković, S.; Marković, B.; Božić, D.; Stojanović, J.; Sokić, M. Investigation of the optimal technology for copper leaching from old flotation tailings of the copper mine bor (Serbia). Metallurgical and Materials Engineering, 2020, 26(2), pp.209222.'

16. Stanojlović, R.D.; Sokolović, J.M.; Milosević, N. Integrated environmental protection and waste minimization in the area of Copper Mine Bor, Serbia. Environmental Engineering \& Management Journal (EEMJ), 2014, 13(4).

17. Han, B.; Altansukh, B.; Haga, K.; Stevanovic, Z.; Radojka, J.; Markovic, R.; Avramovic, L.; Obradoiv, L.; Takasaki, Y.; Masuda, N.; Ishiyama, D. Copper upgrading and recovery process from mine tailing of Bor region, Serbia using flotation. International Journal of the Society of Materials Engineering for Resources, 2014, 20(2), pp.225-229.

18. Serafimovski, T.; Ristovic, I.; Boev, B.; Tasev, G.; Boev, I.; Serafimovski, D.: Dolenec, M. Mineralogical analysis of samples from the old Bor mine flotation tailing, Republic Serbia. Natural Resources and Technologies, 2021, 15(1), pp.37-50.

19. Young, R.S., 1974. Chemical Phase Analysis. London.

20. Lamberg, P.; Hautala, P.; Sotka, P.; Saavalainen, S. Mineralogical balances by dissolution methodology. Proceedings of Short Course on Crystal Growth in Earth Sciences, Mamede de Infesta, Portugal, 8-10 September. International Mineralogical Association. 1997, pp. 1-29

21. Lund, C.; Lamberg, P.; Lindberg, T. Practical way to quantify minerals from chemical assays at Malmberget iron ore operationsAn important tool for the geometallurgical program. Minerals Engineering, 2013, 49, pp.7-16.

22. Metso Outotec, 2021. Outotec HSC Chemistry Software Available online: URL www.hsc-chemistry.com

23. Leja, J. (2007). Surface Chemistry of Froth Flotation. Quebec: Springer. 